\title{
Cholestasis-pigmentary retinopathy-cleft palate syndrome
}

INSERM

\section{Source}

INSERM. (1999). Orphanet: an online rare disease and orphan drug data base.

Cholestasis-pigmentary retinopathy-cleft palate syndrome. ORPHA:1415

Cholestasis-pigmentary retinopathy-cleft palate is a syndrome of multiple congenital malformations, characterized by an association of cleft lip and palate, patchy pigmentary retinopathy (cat's paw), obstructive liver disease (cholestasis, portal hypertension etc.) and obstructive renal disease (ectopic ureteric insertion, obstruction, vesicouretral reflux and hydronephrosis). Gastrointestinal tract involvement (malrotation, gastresophageal reflux etc.) and cardiac involvement (coarctation of aorta, pulmonary artery stenosis, etc.) have also been reported. An overlap with Kabuki syndrome is debated. 